\begin{tabular}{cc|c}
\hline Tar. Bil. Der. & Tarm Bilimleri Dergisi & Journal of Agricultural Sciences \\
& $\begin{array}{c}\text { Dergi web sayfası: } \\
\text { www.agri.ankara.edu.tr/dergi }\end{array}$ & Journal homepage: \\
& www.agri.ankara.edu.tr/journal
\end{tabular}

\title{
Growth and Mortality Rates of Cornu aspersum: Organic Snail Culture System, Black Sea Region
}

\author{
Meryem Yeşim ÇELIKKa, Mehmet Bedrettin DUMAN ${ }^{a}$, Merve SARIIIPEK ${ }^{a}$, Gülşen UZUN GÖREN ${ }^{a}$, Dilara \\ KAYA ÖZTÜRK ${ }^{\mathrm{a}}$, Sedat KARAYÜCEL ${ }^{\mathrm{a}}$ \\ ${ }^{a}$ Sinop University, Faculty of Fisheries and Aquaculture, Sinop, TURKEY
}

\section{ARTICLE INFO}

Research Article

DOI: 10.15832 ankutbd.397585

Corresponding Author: Meryem Yeşim ÇELIK, E-mail: yesimcelik@yahoo.com.tr, Tel: +90 (368) 2876265

Received: 21 February 2018, Received in Revised Form: 17 May 2018, Accepted: 23 May 2018

\begin{abstract}
The study was aimed to examine a snail organic culture system and describe the cultivation properties of Cornu aspersum. The environmental parameters of the culture system and their effects on the growth and mortality rates of $C$. aspersum were determined between November 2014-October 2015. Snails were fed Spinacia sp. (spinach), Urtica sp. (nettles), Brassica oleracea sp (cabbage) and formulated diet. The feeding and growth rates increased with increasing temperature. Shell height growth rate was the highest in spring while the live weight growth rate was the highest in summer. Mortality rate of the baby snail was higher between November 2014 and May 2015 due to stress conditions such as handling and varying temperatures during their first stages of life. High mortality observed in adults could be associated with the spawning activity of the matured snails that caused physiological exhaustion. The result showed that the best culture cycle for C. aspersum was from spring to autumn in Black Sea region and in order to prevent postreproductive mortality, snails reached to marketable size should be harvested.

Keyword: Land snail; Ecological culture; Extensive production
\end{abstract}

(C) Ankara Üniversitesi Ziraat Fakültesi

\section{Introduction}

Cornu aspersum (synonym: Helix aspersa), dominating the world market, are quite abundant in Turkey because of the topographical structure, favorable weather and environmental conditions of the country. Snail exporting is important, since the contribution to the maintenance of economic growth for Turkey (TUIK 2017). However, the snail production is only based on the gathering individuals from wild populations. On the other hand, overharvesting, human impacts and climate change have been affecting the natural snail population and it decreased in the last decade (FAO/ Fishstatj 2018) in Turkey. Therefore, snail farming is necessary to prevent overexploitation and ensure sustainable production for the country.

Appropriate farming system for any given species provides optimal living conditions, supports growth and survival, minimizes risks and optimizes production. Humidity, temperature and feeding are vital factors to control growth and survival for heliciculture. Snails aestivate if the temperature is $>30{ }^{\circ} \mathrm{C}$ and hibernate if the temperature is $<5$ ${ }^{\circ} \mathrm{C}$ (Cobbinah et al 2008). Growth of snails is 
mainly determined by genetic factors, although it is influenced by many other parameters such as stocking density (Dupont-Nivet et al 2000), environmental conditions (Garcia et al 2006), the management and sexual maturation. Reproduction activity could affect the life history of snails. High reproductive activity drains somatic energy reserves (e.g. carbohydrate and lipid) and limits the energy available for biochemical systems. Thus, the cost of reproduction compromises immune function, decreases protection against stress and reduces adult survivorship (Harshman \& Zera 2007). In addition, offspring's mortality is strongly affected by adverse environmental conditions. Adverse environmental conditions cause to increase maintenance costs under adverse environmental conditions and affects survival during early development stage of the gastropoda (Diederich \& Pechenik 2013).

Generally, three snail culture systems are described; intensive (indoor), semi-intensive (indoor/outdoor-mixed) and extensive (outdoor) cultures (Cobbinah et al 2008). Extensive system involves the breeding site which has a protection from the wind, a sprinkler system to keep the substrate moist and troughs made from wood or building blocks covered with plastic netting to hinder predators, requiring minimal financial input (Bryant 1994). Extensive snail farming can be certified as ecological and organic if the soil's conditions and the management are appropriate to the principles of IFOAM (1998). The key principle relates to the integration of wildlife, habitats and farming is the principle of ecology (Toader-Williams \& Golubkina 2009). Begg (2009) also detailed organic principles for snail farming.

C. aspersum, frequently used in snail farming since their high reproductive capacity, can adapt to every climatic and farming condition (Avagnina 2012). It is clear that the future of $C$. aspersum farming has an interesting lucrative potential in Turkey. In this study, we investigated the culture of one-month-old snails in an extensive system according to Begg's organic principles (2009) in Black sea region. It was aimed to test workability and profitability of the system for the Black sea region, to describe the properties of $C$. aspersum farming and reveal practices of heliciculture.

\section{Material and Methods}

One-month-old snails with a mean shell height of $6.68 \pm 0.06 \mathrm{~mm}$ and a mean weight of $0.11 \pm 0.00 \mathrm{~g}$ were used in an extensive culture area located at the Scientific Research Center (SUBITAM) of Sinop University between November 2014-October 2015.

\subsection{Study organism}

Cornu aspersum (synonym: Helix aspersa), a hermaphroditic species, is a terrestrial pulmonate gastropod mollusc. The formation of a thickening and recurving lip at the edge of shell aperture indicates maturation (shell heigh $>27 \mathrm{~mm}$ ) (Daguzan 1982; Begg 2003). The reproductive behaviour involves that snails gets in touch with their tentacles, solidified dart comes out, the genital vebt pushed out and copulation happens (Avagnina, 2012).

\subsection{Establishment of snail culture area}

Extensive snail culture system was examined because of its suitability for the Black Sea regional climate. The culture system was maintained according to Begg's organic heliciculture principles (2009) which includes that a) crops are planted without the use of synthetic fertilizers, b) no chemicals are used in the snail fields, c) crops are planted densely to help prevent weed growth, d) finished crops are ploughed back into the ground as 'green manure' crops, e) physical controls are maintained for unwanted weeds and pests, f) ecological benefits of natural sunlight, organic soil.

110 square meters' area was fenced with a galvanized iron as the perimeter fence with a depth of $35-40 \mathrm{~cm}$ to the bottom and supported by iron posts. The sprinkler irrigation system, connected to water tanks filled with tap water, was established to provide water equitably to the production area. The culture area was divided into three pieces as parallels (B1, B2 and B3) with mesh fences of $9 \mathrm{~m}$ length and $1 \mathrm{~m}$ width and included $80 \mathrm{~cm}$ pathways between experimental fields (Figure 1). The downward 
facing flaps and 4 pieces electric copper wires with a diameter of $0.80 \mathrm{~mm}\left(12\right.$ watts $\left.\mathrm{cm}^{2}\right)$ were integrated to the system to prevent snails from climbing up the sides of the fencing. 8 slight slope wooden boards $(50 \mathrm{~cm} \times 50 \mathrm{~cm})$ were placed in each field for feeding and establishing shelter area for snails. The culture area was covered with greenhouse nylon until May 2015 due to prevent harsh winter conditions. The culture area was covered with a bird protection mesh after removing greenhouse nylon. The roof pitch of the system was oriented according to prevailing wind directions.

Soil in the experimental culture area was analyzed prior to the study. Sandy humus soil was added for improving water holding capacity and organic matter content of the culture area since the soil texture was mostly clayey. $\mathrm{pH}$, organic matter and moisture contents of the soil then were determined.

After excavating soil, three preferred plant types were planted as a row of Spinacia sp. (spinach), urtica $s p$. (nettles) and Brassica oleracea sp (cabbage) to each experimental field in order to determine the most preferred plants. Plants development was monitored and unwanted plants were removed from the experimental areas.

Artificial diet was prepared according to the organic feed rules (Blair 2008). The formulation and biochemical composition of the diet were given in Table 1. Feed was supplied every other day on the wooden boards during sunset time (between 5 and $8 \mathrm{pm}$ ).

Table 1- Ingredient and biochemical composition of diet

\begin{tabular}{lrl}
\hline Diet formulation & \multicolumn{3}{c}{$\begin{array}{l}\text { Biochemical composition of } \\
\text { diet (based dry-weight, \%) }\end{array}$} \\
\hline Soybean flour & 16 Protein & 33.33 \\
Corn gluten & 11 Lipid & 3.85 \\
Wheat flour & 28 Carbohydrate & 22.26 \\
Canola oil & 3 Ash & 40.56 \\
Dicalciu phosphate & 5 Moisture & 3.85 \\
Pectin & 1 & \\
Limestone & 33 & \\
Sodium chloride & 0.5 & \\
Vitamin premix & 1.5 & \\
Mineral premix & 1 & \\
\hline
\end{tabular}

\subsection{Environmental parameters}

Temperature and humidity were measured every morning (9:00 am) and sunset time from inside and outside of the culture area by TFA 5013 (electronic equipment). Natural ventilation was supplied by opening door and window of the greenhouse when temperature increased inside the culture area. Supplemental irrigation was also supplied as needed before sunset time when moisture was deficient.

\subsection{Growth and mortality rate}

300 snails were placed in one square meter of unit (separated with wooden block) in each field (B1, B2 and B3). Then the unit was enlarged by one square meter for every month with increasing growth. One hundred snails was randomly sampled from each field (B1, B2, B3) for the biometric parameters in every week until June, then sampling were carried out every two weeks period. Live weight (total weight of snail) was measured by weighing live animals to the nearest $0.001 \mathrm{~g}$ and shell height was measured to the nearest $0.1 \mathrm{~mm}$ with a caliper (Figure 1).

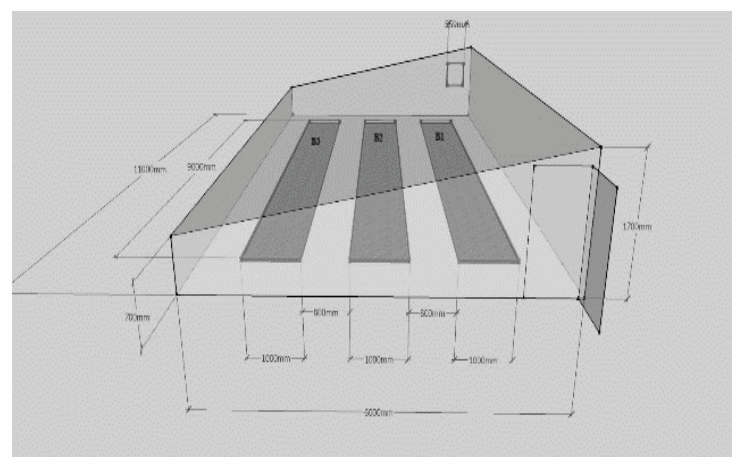

Figure 1- Schematic drawing of the organic snail culture system

Weekly shell height and live weight were calculated on a monthly base to allow for a clear pattern in the growth rates. Monthly shell height growth rate (SHGR \%) and live weight growth rate (LWGR \%) were calculated from the following formulate;

$\operatorname{SHGR}(\%)=\left[\left(L_{2}-L_{1}\right) / L_{1}\right] \times 100$ 


$$
\operatorname{LWGR}(\%)=\left[\left(W_{2}-W_{1}\right) / W_{1}\right] \times 100
$$

Where; $L_{1}$ and $L_{2}$ are the mean shell height and $W_{1}$ and $W_{2}$ are the mean live weight in a month.

The mortality rate was not determined before May due to fragile shells. The first mortality rate was determined in May 2015 by subtracting snails in May from the starting number of snails. After May, empty snail shells were counted and removed to determine mortality rate and followed monthly.

Mortality rate $(\%)=100\left(N_{t}-N_{0}\right)$

Where; $N_{t}$ is the number of dead snails removed after t time and $N_{0}$ is the number of snail at the beginning of the experiment.

\subsection{Statistical analyses}

Data were analyzed for significant differences in means using ANOVA's, with significance levels set at $\mathrm{P}<0.05$ and the normality of the variation of data was verified using the software program MINITAB 16 software. The variability of shell height and live weight were analyzed as the coefficient of variation (CV) in Microsoft Office Excel. A correlation matrix analysis was used to determine the relationships between the environmental and growth parameters.

\section{Results and Discussion}

\subsection{Environmental factors}

Monthly day and night temperature of the culture area (A), temperature of natural and culture environment (B), monthly day and night humidity of the culture area (C) and humidity of natural and cultured environment (D) were shown in Figure 2. Day and night temperature differences was the highest $\left(7.72{ }^{\circ} \mathrm{C}\right)$ in April $(\mathrm{P}<0.05)$. There was no difference in humidity between day and night inside the culture system when greenhouse nylon was covered $(\mathrm{P}>0.05)$ (Figure 3$)$. However, there was significant difference in humidity between day and night after the greenhouse nylon was removed on May $2015(\mathrm{P}<0.05)$. $\mathrm{pH}$, organic matter and moisture values of the soil were $7.00,30.67 \%$ and $24 \%$, respectively.

It is reported that if soil structure is not suitable for snail culture, soil should be improved in order to ensure for healthy development of snails (Begg 2003). In the present study, organic matter in the soil increased by adding humus soil and water permeability increased by adding sandy soil. After soil improvement, the soil structure was suitable for snail and plant breeding. Lucas \& Davis (1961) declared that if soil $\mathrm{pH}$ is around 7.2, it indicates that the soil is rich in calcium. Calcium rich soil is desirable property because it supports shell growth in snail culture.

The observation on developing plants showed that cabbages grew fast in the culture area. The spinach did not grow enough because of the shade of the enlarging cabbage leaves. The leaves of cabbage hardened quickly due to the high growth of the cabbage. However, this situation did not have an adverse effect on the snails feeding since cabbage mostly consumed by snails. Snails started to consume more formulated feed after cabbage leaves. In addition, enlarging cabbage leaves also obstructed to effectively use sprinkler irrigation system. On the other hand, the culture area covered greenhouse nylon was also regulated the circulation of humidity with preventing humidity lose when temperature was higher at the outside.

\subsection{Growth rate}

Matured snails were not within a certain size range because they were collected from nature, therefore no standard growth was achieved from the obtained offspring. Many studies revealed that cultured mature snails should be used for optimal and regular growth (Murphy 2001; Cobbinah et al 2008; Begg 2009). Monthly shell height growth was significantly different $(\mathrm{P}<0.05)$. SHGR was the highest $(8.58 \%)$ in May while LWGR was the highest (4.11\%) in June (Figure 3).

Temperature varied between $11-12{ }^{\circ} \mathrm{C}$ in the culture area until February and there was no significant growth rate in these time intervals. It was 


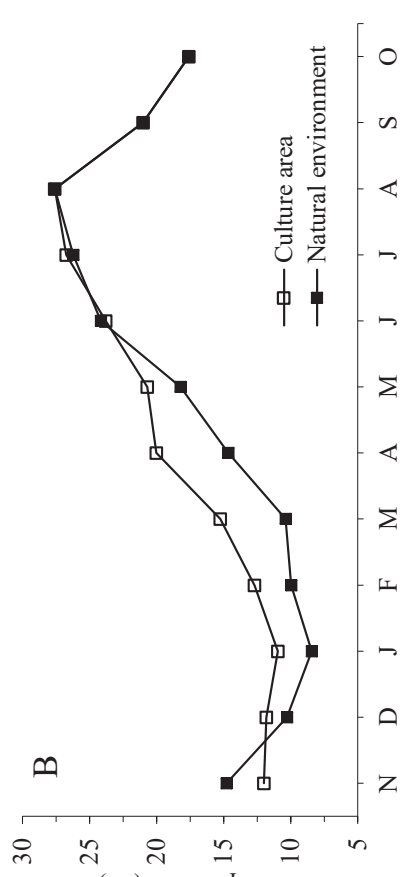

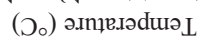

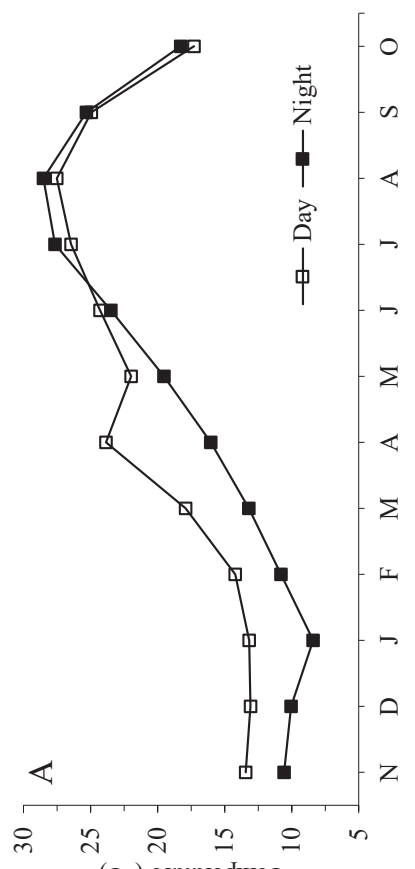

(つ。) әлпц.әәdиә

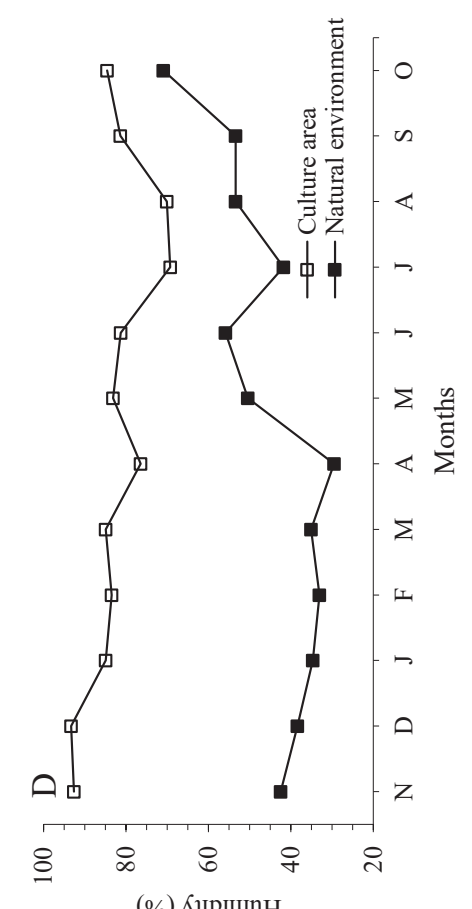

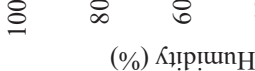

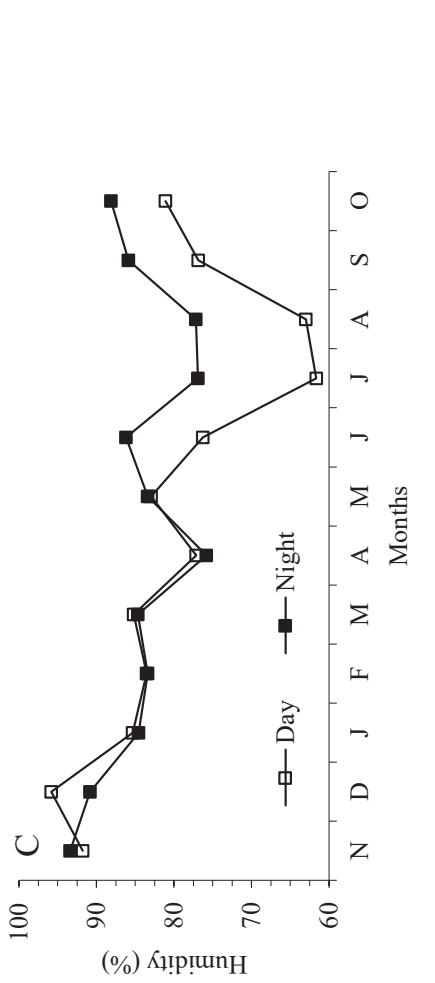

常

를

อำ

๑ิ

를

일

至

e

을

ส

常

를

.

0

节

를 ฮั ङ ฮ อั 늘 豆: 을 클 $\overline{0}$ 를 ํำ 急 을 छ

苞 产 롱 훙 主氞 클 ते ㄱ. 光 일 

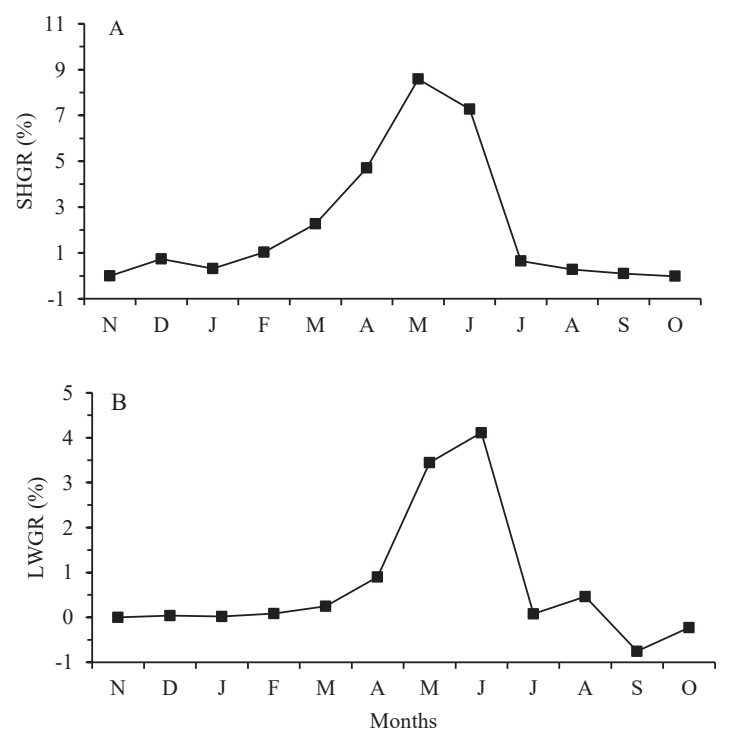

Figure 3- Monthly shell height growth rate (SHGR $\%$ ) (A) and live weight growth rate (LWGR \%) (B) of snails during experiment.

demonstrated that snails were not active below $12{ }^{\circ} \mathrm{C}$ and decreased or stopped feeding. After February, the growth rate increased with the increasing temperature above $12^{\circ} \mathrm{C}$. In April, the feeding rate of snails was increased with the increasing temperature about $19^{\circ} \mathrm{C}$. Furthermore, the highest growth was in May although the temperature difference was significant in April and May. It could be said that snails with the $13.91 \pm 0.28 \mathrm{~mm}$ shell height had better tolerance to environmental stress caused by the difference between night and day. Many studies showed that continuous growth was noticed in spring which demonstrated that most terrestrial snails show a faster growth rate during spring in nature (Staikou et al 1988; Hatziioannou et al 1989). Length growth of land snails' ceases with lip formation and reaches sexual maturation (Choat \& Schiel 1980; Koene \& Ter Maat 2004). In the present study, snails with $31.58 \pm 0.31 \mathrm{~mm}$ shell height growth rate started to decrease after May and reproductive behavior was observed. Daguzan (1982) reported that H. aspersa reached maturity with shell heights reaching over 27 $\mathrm{mm}$ and marketable size of this species is between 25 and $32 \mathrm{~mm}$ (Lazaridou-Dimitriadou et al 1998).
In the present study, $25 \%$ of snails reached shell heights of over $27 \mathrm{~mm}$ within seven months, while $90 \%$ of them reached to the same size in June within eight months. Approximately all of hatched snails reached marketable size in nine months (July 2015). Ligaszewski et al (2007) declared that Helix pomatia needed two year farming cycle from hatching to maturity in an unheated greenhouse farming system in Poland. In Greece, C. aspersum reached marketable size varied from 2.5-5 months indoor farming system (Lazaridou-Dimitriadou et al 1998). The life cycle of $C$. aspersum was highly affected by the climatic conditions of the region (Chevallier 1977) and farming system. In Australia, one third of the hatched snails reached marketable size before they were 12 months old at an extensive system. Lazaridou-Dimitriadou et al (1998) reported that snails reached marketable size in 4-5 months under intensive farming conditions, depending origin, instead of 18 months which is needed in nature.

\subsection{Mortality rate}

Our study showed that offsprings experienced high stress such as variation in weather conditions and handling stress in the first stages of their life-cycles between November and May (Figure 4).

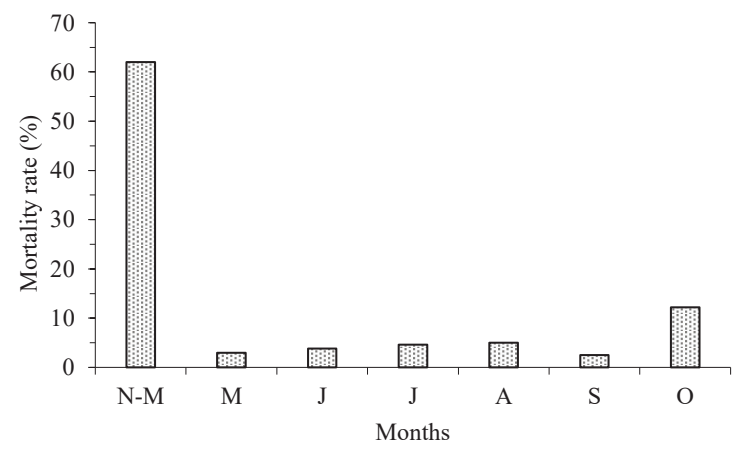

Figure 4- Mortality rate (\%) between November 2014 and October 2015 (N-M: Mortality from November to May)

In November the juvenile snails $(6.68 \mathrm{~mm}$ shell height) were taken from the hatchery (temperature range $18-20{ }^{\circ} \mathrm{C}$; humidity range $84-87 \%$ ) and 
placed to the covered culture area where they were exposed to relatively cold weather and temperature difference. In addition, they were under handling stress caused by the weekly measurement procedure of this sensitive stages. Snails could be damaged during the measurement and were not able to repair their shells since they had low feeding or no feeding rate for generating enough energy for repairing their shells under inappropriate conditions like low temperature. Hence, high mortality was observed between November and May. Many studies revealed that animals has lower ability to tolerate stress during their first stages of life (Zippay \& Hofmann 2010; Gheoca 2013; Diederich \& Pechenik 2013).

Snails showed reproductive behaviors after reaching sexual maturity in May and continued throughout summer and autumn. This showed that snails were constantly mating and producing eggs throughout the summer when suitable environmental was provided. However, high mortality rates were recorded in August, September and October. Negative live weight growth rate was also observed after August due to death of mature snails (Figure 4). Thus, spawning activity of matured snails could affect immune system and caused to postreproductive mortality. Many studies showed similar results that mortality rate was higher in animals showing higher reproductive efforts because of reducing body maintenance and immune capacity, and hence it might cause physiological exhaustion (Baur \& Baur 2000; Barker 2001; Carvalho et al 2008). In addition, farming system types, snail species and rearing density also effect snails' mortality rate. Dupont-Nivent (2000) reported quite high mortality of C. aspersum as $21 \%$ in indoor system in France. Ogogo et al (2011) found 1.4\% cumulative mortality of Archactina spp. in survey of snail farming (farming systems: concrete trench, wire quaze fence, wooden cage) in Nigeria.

\section{Conclusions}

Additional studies should be carried out to further investigate which plants should be grown together without competition with the others for snail farming at the Black sea region.
More controllable system should be established to minimize the difference between night and day temperatures in the winter months, and therefore, low mortality and increased growth rate could be obtained.

The largest and the same sized mature snails should be selected as much as possible for breeding stock from the initial collected wild snails to obtain uniform growth of offspring and for successful breeding.

The most suitable environmental conditions for snail culture were provided during the SpringSummer-Autumn seasons in the Black Sea region. The production activities might be more efficient with the addition of shading and irrigation at these seasons to reduce the effect of hot and dry air in summer. However, irrigation should be carried out according to temperature value of the environment to prevent snails from thermal stress.

After snails reached the market size which is the same size at maturation, breeding stock should be separated and the rest should be immediately harvested. Otherwise, mature snails will continue to reproduce which causes mortality by physiological exhaustion.

\section{Acknowledgements}

This research has been supported by The Scientific and Technological Research Council of Turkey (TUBITAK). Project Number: 114O106. We thank for providing financial support.

\section{References}

Avagnina G (2012). Snail Breeding. Cherasco, Italy: The International Snail Breeding Institute. Print

Barker G M (2001). The Biology of Terrestrial Molluscs. CABI Publishing, Wallingford, USA

Baur B \& Baur A (2000). Social facilitation affects longevity and lifetime reproductive success in selffertilizing land snail. Oikos 88: 612-620

Begg S (2003). Farming Edible Snails. Lessons from Italy. Rural Industries Research and Development Corporation

Begg S (2009). Code of Practice Australian FreeRange Snail Farming (Heliciculture). Orange NSW Australia. Rural Industries Research and Development Corporation 
Blair R (2008). Nutrition and Feeding of Organic Poultry. CAB International, Wallingford, Oxford, UK

Bryant R (1994). Heliciculture: Culture of edible snails. Farm Structures Factsheet. 1 January

Carvalho C M, Bessa E C A \& Davila S (2008). Life history strategy of Bradybaena similaris (Férussac, 1821) (Mollusca, Pulmonata, Bradybaenidae). Molluscan Research 28: 171-174

Chevallier H (1977). La variabilité de léscargot petit-gris Helix aspersa Müller. Bulletin du Muséum national d'histoire naturelle (Paris) 448: 425-442

Choat J H \& Schiel D R (1980). Population structure of Placostylus hongii (Gastropoda: Paryphantidae) on the Poor Knights Islands. New Zealand Journal of Zoology 7(2): 199-205

Cobbinah J R, Vink A \& Onwuka B (2008). Snail farming: Production, Processing and Marketing. Agrodok- Series No. 47, Agromisa Foundation, CTA, Wageningen

Daguzan J (1982). Contribution àl'élevage de l'escargot Petit-Gris: Helix aspersa Müller (Mollusque Gastéropode Pulmoné stylommatophore). II-Evolution de la population juvénile de l'éclosion àl'age de 12 semaines, en bâtiment et en conditions dàlevage contrôleé. Annales De Zootechnie 31: 87-110

Diederich C M \& Pechenik J A (2013). Thermal tolerance of Crepidula fornicata (Gastropoda) life history stages from intertidal and subtidal subpopulations. Marine Ecology Progress Series 46: 173-187

Dupont-Nivet M, Coste V, Coinon P, Bonnet J \& Blanc J (2000). Rearing density effect on the production performance of the edible snail Helix aspersa Müller in indoor rearing. Annales De Zootechnie 49: 447-456

FAO/Fishstatj (2018). Global aquaculture production dataset 1970-2016. Fishery statistics data bases, downloadable with Fishstatj-Plus software. Rome, Italy. Available at: http://www.fao.org/fishery/ statistics/software/fishstatj/en. (16.03.2019)

Garcia A, Perea J M, Mayoral A, Acero R, Martos J, Gomez G \& Pena F (2006). Laboratory rearing conditions for improved growth of juvenile Helix aspersa Müller snails. Laboratory Animals 40: 309-316

Gheoca V (2013). An Heliciculture Act As A Tool For Edible Land Snails'Natural Populations' Management in Romania? Management of Sustainable Development Sibiu 2(5): 21-25

Harshman L \& Zera A (2007). The cost of reproduction: the devil in the details. Trends in Ecology and Evaluation 2(22): 80-86
Hatziioannou M, Eleutheriadis N, Lazaridou-Dimitriadou M \& Kattoulas M (1989). Contribution à la reproduction de l'escargot comestible Helix pomatia rhodopensis (Kobelt 1906) vivant dans la Gréce du Nord-est. Haliotis 19: 137-141

IFOAM (1998). Basic standards for Organic Production and Processing. IFOM, Theley, Germany

Koene J M \& Ter Maat A (2004). Energy budgets in the simultaneously hermaphroditic pond snail, Lymnaea stagnalis: A trade-off between growth and reproduction during development. Belgian Journal of Zoology 134(2): 41-45

Lazaridou-Dimitriadou M, Alpoyanni E, Baka M, Brouziotis T, Kifonidis N, Mihaloudi E, Sioula D \& Vellis G (1998). Growth, mortality and fecundity in successive generations of Helix aspersa Müller cultured indoors and crowding effects on fast-, medium-and slow-growing snails of the same clutch. Journal of Molluscan Studies 64: 67-74

Lucas R E \& Davis J F (1961). Relationships between pH values of organic soils and availabilities of 12 plant nutrients. Soil Science 92: 171-182

Murphy B (2001). Breeding and growing snails commercially in Australia: a report for the rural industries research and development corporation. RIRDC Publication, Australia

Ogogo A U, Ijeomah H M \& Effiong K M (2011). a Asurvey of snail farming in Akwa Ibom State, NIGERIA. Electronic Journal of Environment, Agriculture and Food Chemistry 10(2): 1935-1942

Staikou A, Lazaridou-Dimitriadou M \& Farmakis N (1988). Aspects of the life cycle, population dynamics, growth and secondary production of the edible snail Helix 1ucorum L. in Greece. Journal of Molluscan Studuies 54: 139-155

Toader-Williams A \& Golubkina N (2009). Investigation upon the edible snail's potential as source of selenium for human health and nutrition observing its food chemical contaminant risk factor with heavy metals. Bulletin UASVM Agriculture 66(2): 495-499

TUIK (2017). Turkish Statistic Department, Fishery Statistic, www.tuik.gov.tr (Accessed: 18 November 2017 in Turkish)

Zippay M L \& Hofmann G E (2010). Physiological tolerances across latitudes: thermal sensitivity of larval marine snails (Nucella spp.). Marine Biology 157: $707-714$ 